\title{
ANALISIS PENGARUH BIMBINGAN ORANG TUA TERHADAP PRESTASI AKADEMIK MAHASISWA
}

\author{
Mufrida Zein ${ }^{1}$, Luthfina Ariyani ${ }^{2}$ \\ ${ }^{1}$ Politeknik Negeri Tanah Laut \\ ${ }^{2}$ Politeknik Negeri Tanah Laut \\ Email: ${ }^{1}$ mufridazein@yahoo.co.id, ${ }^{2}$ luthfina.ariyani@gmail.com
}

\begin{abstract}
Abstrak
Dalam hal pendidikan formal baik tingkat sekolah maupun perguruan tinggi, baik atau buruknya tingkat pendidikan seseorang biasanya diukur melalui prestasi yang didapatkan, oleh karena itu penelitian ini dilakukan untuk menganalisis hubungan bimbingan orang tua dan prestasi mahasiswa Politeknik Negeri Tanah Laut tahun angkatan 2015. Penelitian dilakukan dengan membagikan kuesioner kepada 147 mahasiswa yang selanjutnya dianalisis melalui analisis korelasi product moment. Berdasarkan penelitian yang telah dilakukan, dapat disimpulkan bahwa tidak terdapat hubungan antara bimbingan orang tua dengan prestasi akademik mahasiswa angkatan 2015 Politeknik Negeri Tanah Laut karena nilai signifikasi dalam perhitungan yang bernilai 0.187 bernilai lebih besar dibandingkan dengan level signifikansi yang menjadi acuan yaitu sebesar 0.05. Lebih jauh, nilai koefisien korelasi yang dihasilkan pun menunjukkan tingkat korelasi yang sangat lemah yaitu sebesar 0.109. Hal ini dapat terjadi karena pada dasarnya anak ditingkat perguruan tinggi telah lebih mandiri sehingga bimbingan orang tua tidak berpengaruh secara langsung terhadap prestasi mereka.
\end{abstract}

Kata Kunci: Analisis Korelasi, Bimbingan Orang Tua, Prestasi Mahasiswa

\section{Abstract}

In terms of formal education, both school and college level, how good or poor the person's education level is usually measured through the achievements earned, therefore this research was conducted to analyze the relationship between parental guidance and achievement of Politeknik Negeri Tanah Laut Student. There were 147 questionaires distributed to the students and analyzed through product moment correlation analysis. Based on the research that has been conducted, it can be concluded that there is no correlation between parental guidance with the academic achievement of Politeknik Negeri Tanah Laut because the value of significance in the calculation is worth 0.187 which is greater than the reference level of significance 0.05. Furthermore, the resulting correlation coefficient also shows a very weak correlation level 0.109. This situation may occur since basically students at the college level have been more independent so that the parental guidance does not directly affect their achievements.

Keywords: College Student Achievement, Correlation Analysis, Parental Guidance

\section{PENDAHULUAN}

Pendidikan merupakan suatu cara dalam rangka pengembangan (Anwar, 2009) kualitas sumber daya manusia. Dalam hal pendidikan formal baik tingkat sekolah maupun perguruan tinggi, baik atau buruknya tingkat pendidikan seseorang biasanya diukur melalui prestasi yang didapatkan. Mendapatkan prestasi yang baik tentu saja merupakan keinginan bagi setiap orang, namun hal tersebut tidak lepas dari berbagai faktor yang mempengaruhinya. Slamento (2010) mengatakan bahwa faktor yang mempengaruhi prestasi seseorang terdiri dari faktor internal dan faktor eksternal. Faktor inernal terdiri dari faktor jasmani orang yang bersangkutan, keadaan psikologis, dan faktor kelelahan. Sementara itu, faktor eksternal terdiri dari faktor keluarga, sekolah, dan masyarakat. Walaupun terdapat banyak faktor yang mempengaruhi prestasi akademik seseorang, namun Hara dan Burke (1998) menyebutkan bahwa salah satu faktor terpenting yang mempengaruhi prestasi akademik adalah keterlibatan orang tua 
dalam membimbing. Hal tersebut juga sejalan dengan apa yang dinyatakan oleh Rafiq, dkk. (2013) yang menyebutkan bahwa prestasi akademik anak mungkin tidak hanya bergantung pada kualitas sekolah dan pengajar, namun tingkat keterlibatan orang tua memiliki peran penting dalam pencapaian akademik anakanak mereka.

$\begin{array}{ccc}\text { Berbagai penelitian telah } & \text { dilakukan } \\ \text { untuk mengidentifikasi } & \text { hubungan }\end{array}$
bimbingan orang tua terhadap prestasi anak. Seperti yang dilakukan oleh Setiyani (2015) yang meneliti tentang korelasi bimbingan orang tua dengan prestasi siswa sekolah dasar. Selain itu, Hendriyanto (2016) juga melakukan penelitian menganalisis peran bimbingan orang tua terhadap prestasi belajar siswa sekolah menengah atas. Dari beberapa studi literatur yang telah didapatkan, dapat diidentifikasi bahwa kebanyakan penelitian terkait dengan analisis hubungan bimbingan orang tua dan prestasi anak ditujukan bagi siswa sekolah dasar, sekolah menengah pertama, ataupun sekolah menengah atas. Sementara belum terdapat banyak penelitian yang membahas tentang peran bimbingan orang tua terhadap prestasi belajar mahasiswa di perguruan tinggi Sehingga perlu adanya penelitian yang ditujukan sebagai pembuktian apakah bimbingan orang tua mempengaruhi prestasi anak pada jenjang pendidikan perguruan tinggi sama seperti halnya bimibingan oran tua mempengaruhi prestasi anak pada tingkat sekolah.

\section{METODE PENELITIAN}

Penelitian analisis bimbingan orang tua dan prestasi mahasiswa dilakukan pada mahasiswa Politeknik Negeri Tanah Laut angkatan 2016 pada jurusan Teknologi Industri Pertanian, Teknik Informatika, dan Mesin Otomotif. Sebanyak 147 kuesioner diberikan kepada mahasiswa untuk mengidentifikasi tingkat bimbingan orang tua mahasiswa yang bersangkutan. Sementara itu prestasi mahasiswa diukur melalui nilai Indeks Prestasi Kumulatif (IPK).

Kuesioner identifikasi bimbingan orang tua berisi 36 pernyataan yang disusun berdasarkan kriteria dari Slamento (2010) yang menyebutkan bahwa faktor keluarga yang mempengaruhi prestasi siswa adalah sebagai berikut.

1) Cara mendidik, orang tua yang memanjakkan anaknya, maka setelah anak sekolah akan menjadi siswa yang kurang bertanggung jawab dan takut menghadapi tantangan kesulitan. Juga orang tua yang terlalu keras mendidik anak mengakibatkan anak menjadi penakut.

2) Suasana keluarga, hubungan keluarga yang kurang harmonis, menyebabkan anak kurang semangat untuk belajar.Suasana yang menyenangkan, akrab dan penuh kasih sayang akan memberi motivasi yang mendalam.

3) Pengertian orang tua, anak dalam belajar perlu dorongan dan pengertian orang tua. Bila anak sedang belajar jangan diganggu tugas-tugas rumah. Apabila anak mengalami kesulitan di sekolah diharapkan orang tua untuk membantu memecahkan kesulitan tersebut, orang tua memberi dorongan semangat kepada anaknya.

4) Keadaan sosial ekonomi keluarga, anak dalam belajar kadang-kadang memerlukan sarana yang kadangkadang mahal. Bila keadaan ekonomi keluarga tidak mencukupi, dapat menjadi penghambat anak dalam belajar.

5) Latar belakang kebudayaan, tingkat pendidikan atau kebiasaan di dalam keluarga, mempengaruhi sikap anak dalam belajar. Perlu ditanamkan kepada anak kebiasaan-kebiasaan yang baik agar mendorong semangat anak dalam belajar. 
Sementara itu, teknik analisis data yang dilakukan dalam penelitian ini adalah meliputi Uji validitas dan reliabilitas instrumen untuk mendapatkan item kuesioner yang valid dan reliabel. Selanjutnya dilakukan uji prasyarat analisis yaitu uji normalitas dan uji linearitas. Jika data telah memenuhi persyaratan normal dan linear, maka selanjutnya dilakukan analisis korelasi product moment.

\section{HASIL DAN PEMBAHASAN}

\section{Uji Validitas dan Uji Reliabilitas Instrumen}

Uji validitas instrumen dilakukan dengan rumus korelasi product moment. Teknik ini dilakukan dengan mengorelasikan skor masing-masing item pertanyaan (X) terhadap skor total instrument (Y). Uji validitas instrumen dilakukan dengan menggunakan software SPSS 24. Berdasarkan hasil uji validitas instrumen tersebut diperoleh bahwa dari 36 butir item kuesioner yang ada, terdapat 32 butir item pernyataan bernilai valid karena memiliki nilai $r_{\text {hitung }}$ yang lebih besar dibandingkan dengan nilai $r_{\text {tabel }}$ untuk tingkat signifikansi 5\%. Sementara itu, terdapat 4 butir item yang bernilai tidak valid dan dianggap gugur. 4 butir item tersebut terdiri dari item nomor 1, 4, 22, 28.

Sementara itu, uji reliabilitas yang dilakukan menunjukkan nilai cronbach alpha sebesar 0.819 yang bernilai lebih besar dari 0.600 sehingga kuesioner ini telah memenuhi syarat reliabilitas.

\section{Uji Normalitas}

Uji normalitas dalam penelitian ini dilakukan dengan menggunakan rumus Kolmogorov-Smirnov dengan software SPSS 24.0 Kriteria yang digunakan dalam menentukan apakah data terdistribusi normal atau tidak adalah melalui nilai koefisien Asymp. Sig pada output Kosmogorov-Smirnovtest. Jika nilai koefisien Asymp. Sig bernilai lebih dari level signifikansi 5\% (0.05) maka data dapat dikatakan terdistribusi normal. Tabel 1 berikut menunjukkan nilai koefisien Asymp. Sig untuk variabel bimbingan orang tua dan prestasi akademik mahasiswa.

TABEL 1

HASIL PERHITUNGAN UJI NORMALITAS PADA SPSS 24.0

\begin{tabular}{|c|c|c|c|c|}
\hline No & $\begin{array}{c}\text { Variab } \\
\text { el }\end{array}$ & $\begin{array}{c}\text { Asymp } \\
\text {.Sig }\end{array}$ & $\begin{array}{c}\text { Level } \\
\text { Signifikan } \\
\text { si }\end{array}$ & $\begin{array}{c}\text { Kesimpu } \\
\text { lan }\end{array}$ \\
\hline 2. & $\begin{array}{c}\text { Bimbin } \\
\text { gan } \\
\text { Orang } \\
\text { Tua }\end{array}$ & 0.200 & 0.05 & Normal \\
\hline & $\begin{array}{c}\text { Prestasi } \\
\text { Akade } \\
\text { mik } \\
\text { Mahasi } \\
\text { swa }\end{array}$ & 0.200 & 0.05 & Normal \\
\hline
\end{tabular}

Berdasarkan Tabel 1 di atas, dapat diketahui bahwa baik variabel Bimbingan Orang Tua maupun Prestasi Akademik Mahasiswa memiliki nilai Asymp. Sig yang lebih besar dibandingkan dengan nilai level signifikasi. Sehingga, dapat dikatakan bahwa variabel Bimbingan Orang Tua dan Prestasi Akademik Mahasiswa telah terdistribusi normal.

\section{Uji Linearitas}

Pengujian prasyarat berikutnya adalah terkait dengan pengujian linearitas data. Uji linearitas juga dilakukan dengan menggunakan software SPSS 24.0. Berdasarkan hasil perhitungan diketahui nilai sig deviation from linearity adalah sebesar 0.907. Nilai ini lebih besar jika dibandingkan dengan nilai level signifikasi 5\%. Sehingga variabel Bimbingan Orang Tua dan Prestasi Akademik Mahasiswa dapat dikatakan memiliki hubungan yang linear.

\section{Analisis Korelasi Product Moment}


Analisis Korelasi Product Moment dilakukan untuk mengetahui apakah terdapat hubungan antara bimbingan orang tua dengan prestasi akademik mahasiswa. Berdasarkan hasil pengolahan data yang dilakukan, diketahui bahwa nilai signifikasi yang didapatkan adalah sebesar 0.187. Nilai ini lebih besar dibandingkan dengan level signifikasi 5\% yang menjadi acuan yang berarti bahwa tidak terdapat hubungan antara variable Bimbingan Orang Tua dengan Prestasi Akademik Mahasiswa. Lebih jauh, hasil pengolahan data juga menunjukkan nilai koefisien korelasi (r) adalah sebesar 0.109. Sementara itu, Sugiyono (2008) memberikan pedoman dalam interpretasi kuat atau tidaknya suatu korelasi berdasarkan nilai koefisien korelasinya yang ditampilkan pada tabel 2 berikut.

TABEL 2.

PEDOMAN INTERPRETASI KOEFISIEN KORELASI (SUGYIONO,2010)

\begin{tabular}{|c|c|}
\hline $\begin{array}{c}\text { Koefisien Korelasi } \\
(\mathbf{r})\end{array}$ & Interpretasi \\
\hline $0-0.199$ & Sangat Lemah \\
\hline $0.20-0.399$ & Lemah \\
\hline $0.40-0.599$ & Sedang \\
\hline $0.60-0.799$ & Kuat \\
\hline $0.80-1.00$ & Sangat Kuat \\
\hline
\end{tabular}

Berdasarkan Tabel 2 di atas, maka dapat diketahui bahwa nilai koefisien korelasi dari variabel Bimbingan Orang Tua dan Prestasi Akademik Mahasiswa yang bernilai 0.109 memiliki korelasi yang sangat lemah. Hal ini berarti peningkatan ataupun penurunan bimbingan orang tua tidak serta-merta mempengaruhi peningkatan atau penurunan prestasi akademik mahasiswa. Gambar 1 menunjukkan hubungan antara Bimbingan Orang Tua dengan Prestasi Akademik Mahasiswa. Jika dilihat pada Gambar 1 garis linear yang terbentuk dari hubungan kedua variabel sangat landai. Hal ini berarti bahwa perubahan pada nilai Bimbingan Orang Tua tidak akan mengubah nilai Prestasi Akademik Mahasiswa secara signifikan.

Walaupun pada beberapa penelitian mengatakan terdapat hubungan antara Bimbingan Orang Tua dengan Prestasi Akademik anak (Setiyani, 2015; Hendriyanto, 2016) namun penelitian ini menunjukkan hasil yang berbeda yang mengidentifikasi bahwa tidak terdapat hubungan antara kedua variabel tersebut. Salah satu hal yang mungkin menjadi faktor yang membedakan hasil penelitian ini adalah karena objek penelitian ini adalah para mahasiswa, sementara yang menjadi objek penelitian yang dilakukan oleh Setiyani (2015) dan Hendriyanto (2016) adalah siswa sekolah, baik Sekolah Dasar (SD), Sekolah Menengah Pertama (SMP), maupun Sekolah Menengah Atas (SMA). Seperti yang diketahui bahwa mahasiswa memiliki sifat yang cenderung lebih mandiri dibandingkan dengan siswa sekolah, sehingga bimbingan orang tua menjadi lebih berpengaruh terhadap prestasi siswa dibandingkan dengan prestasi mahasiswa. Hal ini sejalan dengan apa yang dinyatakan oleh Rafiq, dkk. (2013) yang menyebutkan bahwa keterlibatan orang tua akan lebih berkurang terhadap mahasiswa.

Selain itu, menurut Becker dan Epstein (1982) menyatakan bahwa keterlibatan orang tua dalam prestasi anak dilakukan melalui aktivitas umum seperti aktivitas membaca, pembelajaran melalui diskusi, melakukan supervisi dalam pengerjaan tugas, dan menjalin hubungan dengan pihak pengajar. Sementara, bagi anak dengan 
jenjang pendidikan perguruan tinggi, aktivitas tersebut sudah tidak perlu lagi dilakukan mengingat anak dapat melakukannya secara mandiri. Sehingga dapat dikatakan bahwa semakin tinggi jenjang pendidikan anak, maka keterlibatan orang tua secara langsung akan semakin berkurang.

\section{KESIMPULAN}

Berdasarkan penelitian yang telah dilakukan, dapat disimpulkan bahwa tidak terdapat hubungan antara bimbingan orang tua dengan prestasi akademik mahasiswa angkatan 2015 Politeknik Negeri Tanah Laut karena nilai signifikasi dalam perhitungan yang bernilai 0.187 bernilai lebih besar dibandingkan dengan level signifikansi yang menjadi acuan yaitu sebesar 0.05. Lebih jauh, nilai koefisien korelasi yang dihasilkan pun menunjukkan tingkat korelasi yang sangat lemah yaitu sebesar 0.109. Oleh karena itu, untuk mengetahui lebih jauh variabel yang mempengaruhi prestasi akademik mahasiswa perlu adanya identifikasi variabel-variabel lainnya. Variabel yang mungkin dipertimbangkan untuk dapat dianalisis lebih lanjut dapat berupa faktor internal seperti motivasi belajar dan tingkat kehadiran ataupun tingkat perhatian mahasiswa.

\section{DAFTAR PUSTAKA}

Anwar, Chairul. 2009. Strategi Pendidikan dalam Meningkatkan Kualitas Sumber
Daya Manusia (Studi Komparasi atas Pemikiran Ki Hajar Dewantara dengan Hasan Langgulung). Skripsi. Universitas Islam Negeri Syarif Hidayatullah.

Becker, H., dan Epstein, J. 1982. Parent Involvement: A Survey of Teacher Practices. The Elementary School Journal. No. 83. pp. 85-102.

Hara, S.R., dan Burke, D.J. 1998. Parent Involvement: The Key To Improved Student

Achivement. The School Community Journal. Vol. 8. No. 2. pp 9-19.

Hendriyanto, M.N. 2016. Peran Bimbingan Orang Tua terhadap Prestasi Belajar Siswa Kelas XI Teknik Kendaraan Ringan di SMK 45 Wonosari. Skripsi. Universitas Negeri Yogyakarta.

Rafiq, H.M.W., Fatima, T., Sohail, M.M., Saleem, M., dan Khan, M.A. 2013. Parental Involvement and Academic Achievement; A Study on Secondary School Student of Lahore, Pakistan. International Journal of Humanities and Social Science. Vol. 3, No.8. pp. 209-223

Setiyani, I. 2015. Korelasi antara Bimbingan Belajar Orang Tua dengan Prestasi Belajar Siswa di SDN Premulung No. 94 Surakata Tahun Ajaran 2014/2015. Skripsi. Universitas Muhammadiyah Surakarta.

Slameto. 2010. Belajar dan Faktor-Faktor Yang Mempengaruhiya. Jakarta: Rineka Cipta. Sugiyono. 2007. Metode Penelitian Administrasi. Bandung:Alfabeta

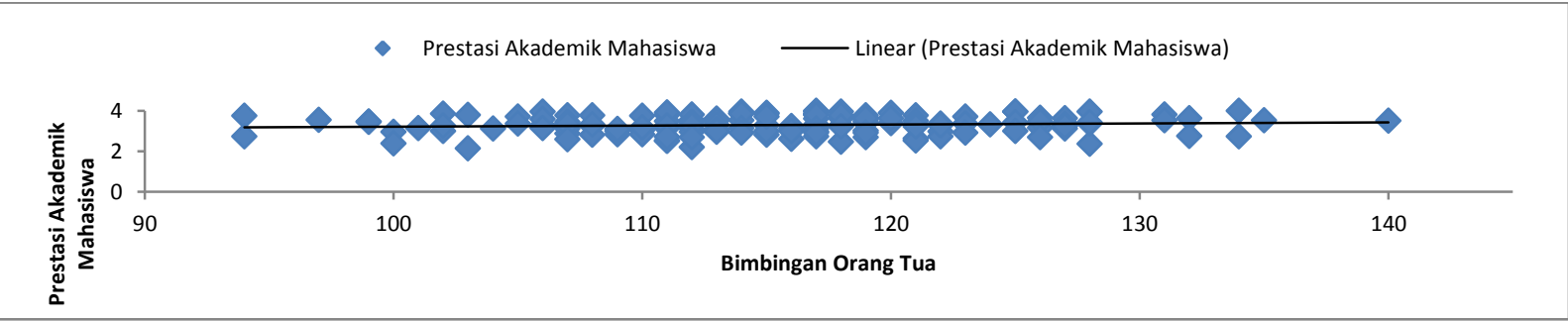

Gambar 1. Hubungan Variabel Bimbingan Orang Tua Dengan Prestasi Akademik Mahasiswa 